\title{
Er seleksjon av dove eller horende barn to sider av samme sak? En bioetisk argumentasjon basert på
autentisitetsbetraktninger
}

\author{
Patrick Kermit
}

I denne teksten blir følgende spørsmål tatt opp til drøfting: Er det å ta medisinsk teknologi i bruk for å selektere et døvt barn mer etisk problematisk enn det motsatte; å bruke teknologien for å sikre seg et hørende barn? På bakgrunn av fire premisser konkluderer jeg med at både seleksjon for døvhet og for hørsel er tilnormet like etisk problematisk. De fire premissene er 1) at seleksjonskriteriet sykdom eller skade bør erstattes av autentisitetsbetraktninger, 2) at døve og hørende har samme potensial for autentisk livsutfoldelse, selv om det ikke kan avvises at døvhet kjennetegnes ved manglende hørsel, 3) at seleksjon inneboerer fravalg av liv som har autentisk potensialitet enten som døv eller hørende, og 4) at dette fravalget involverer en etisk kostnad. Konklusjonen har enkelte andre implikasjoner og en restproblematikk som belyses avslutningsvis.

Nøkkelord: medisinsk teknologi, seleksjon, autentisitet, døvhet, tegnspråk

\section{Innledning}

Er det å ta medisinsk teknologi i bruk for å selektere et døvt barn mer etisk problematisk enn det motsatte; å bruke teknologien for å sikre seg et hørende barn?

Da det i 2002 ble kjent at et døvt lesbisk par bosatt i USA med vitende og vilje hadde gått inn for å få døve barn, ble dette spørsmålet umiddelbart tatt opp i de bioetiske diskursene om bruk av reproduktiv medisinsk teknologi, 
seleksjon og fravalg av fremtidig syke eller funksjonshemmede barn samt mer generelle diskurser om forståelsen av funksjonshemming (se f.eks. Anstey 2002; Harris 2002; Hayry 2004; Johnston 2005; Savulescu 2002). Jeg vil her argumentere for at man ikke kan forsvare verken seleksjon av et fremtidig døvt eller et fremtidig hørende barn. Begge deler er tilnærmet like problematisk. Jeg bygger mitt resonnement på fire premisser:

Første premiss er at fysisk skade eller sykdom er lite egnet som enkeltstående seleksjonskriterium så lenge mange som selv er døve, kan argumentere for at dette er et sekundært kjennetegn ved begrepet om døvhet som funksjonshemming. Derimot bruker mange døve et autentisitetsargument som gir mulighet for noe mer enn en fysisk sammenligning av døve og hørende mennesker. Dette kan utnyttes i denne formen for bioetisk diskusjon.

Andre premiss er at et livsprosjekt som døv har samme potensial for å bli autentisk som livsprosjektet til en hørende person. Begrepet om autentisitet brukes med henvisning særlig til Charles Taylor (1989; 1992a; 1992b). Jeg avviser den enkle dikotomien mellom medisinsk og kulturell døvhet som ellers ofte har vært sentral i denne sammenhengen. Istedenfor bygger premissen på en oppfatning av døvhet som forutsetter en forståelse hvor forholdet mellom naturgitte og kulturelle faktorer er gjensidig forenelig.

Tredje premiss er at tilvalg av bestemte genetiske egenskaper hos ett fremtidig barn kan innebære at en eller flere andre livsformer med potensial til å bli barn, fravelges. Dette er ikke i seg selv en verdiladet premiss, men mer en klargjøring av hva medisinsk reproduktiv teknologi i dag kan gjøre.

Fjerde premiss argumenterer for at det er en etisk omkostning forbundet med fravalg av en eller flere livsformer med potensial til å bli barn. Selv om man ikke avviser at denne omkostningen kan forsvares i noen tilfeller, bør man kunne forsvare tydelig at det som fravelges og det som utvelges, har betydelig forskjellig potensial for autentisk livsutfoldelse. Å velge mellom to presumptivt likestilte autentiske livsprosjekter (som ved kjønnsseleksjon) forsvarer ikke den etiske omkostningen som kan være involvert ved selve seleksjonen.

Én implikasjon av den overnevnte konklusjonen disse premissene indikerer, er at det er etisk uproblematisk om et par unnfanger et barn selv om de vet at barnet kan bli døvt på grunn av arvelige faktorer. I tilfellet med det nevnte døve lesbiske paret oppstår det imidlertid en interessant restproblematikk som kort belyses i den avsluttende drøftingen. Her kommenterer jeg også mer prinsipielt hva slags rekkevidde den etiske argumentasjonen her bør anses å ha, satt opp mot andre mulige vurderinger.

Diskusjonen i denne teksten er avgrenset til å gjelde døve mennesker, og jeg tar i utgangspunktet ikke stilling til hvorvidt autentisitetsbegrepet som er sentralt i premissene én, to og fire kan ha relevans for andre diskusjoner. Likevel foretar jeg avslutningsvis noen korte vurderinger av hvordan autentisitetsargumentet forholder seg til beslektede argumenter om menneskeverd, leveverdig liv og livskvalitet. 


\section{Forste premiss: skade eller sykdom som uegnet enkeltstående seleksjonskriterium i forhold til dovhet}

Da det ble kjent (Mundy 2002; Meland 2002; Mills 2002) at Candy McCullough og Sharon Duchesneau hadde fått en døv sønn med assistanse fra en sæddonor med en arvelig disposisjon for døvhet, var dette noe som utfordret forestillingen om at sykdom eller skade konstituerer noe potensielt uønsket. Flere bioetikere som har ytret seg kritisk, uttrykker ubehag ved at det de ser som en grunnleggende premiss i diskusjonen om seleksjon, blir utfordret: Både John Harris (2000; 2002), Julian Savulescu (2002) og Trevor Johnston (2005) insisterer på at det er det fysiske fraværet av hørsel som dypest sett konstituerer døvhet som en funksjonshemming, og de avviser andre og mer sosialt baserte faktorer:

Deafness is a disability [...] because there is a real loss of expected function [...]. The disadvantages an individual may experience due to a disability are not purely the result of the social construction of that disability. (Johnston 2005: 434)

Bakgrunnen for denne insisteringen på at et naturgitt forhold (det fysiske hørselstapet) må veie tyngst når døvhet vurderes som mindre attraktivt enn det å høre, er den etter hvert velkjente tilsynelatende antinomien mellom det å være døv (med liten «d») og Døv (med stor «D»). Dette skillet ble foreslått i en artikkel av Harry Markowitz og James Woodward i 1978 og er beskrevet (i en fotnote) som følger:

Throughout this paper we use the convention of capitalizing the word «Deaf» when it refers to any aspect of the Deaf community and its members. Uncapitalized «deaf» refers to the audiological condition of deafness. (Markowicz \& Woodward 1978: 34)

Markowitz og Woodward hadde ingen systematisk teori knyttet til denne distinksjonen. Den reflekterte snarere et behov for en ny term da man på tidspunktet da dette ble skrevet, var i ferd med å ta inn over seg implikasjonene av den lingvistiske forskningen som siden begynnelsen av sekstitallet med stadig økende sikkerhet kunne dokumentere at tegnspråkene til Døve (og noen hørende) mennesker er fullstendige, naturlige språk som ikke på noen måte står tilbake for talte språk. Alt man er i stand til å gjøre med et talt språk, kan man altså også gjøre med et tegnspråk (Armstrong, Karchmer \& Van Cleve 2002; Endresen, Simonsen \& Sveen 1996; Stokoe Jr. 2005).

Det som er felles for døve som ble døve før de lærte et talespråk, og som kom i kontakt med andre døve som brukte tegnspråk i noenlunde tidlig alder (på døveskolen for eksempel) er at tegnspråk er deres førstespråk, en term som grovt sett tilsvarer dagligtalebegrepet morsmål. Dette har sjeldent noe med familiær arv å gjøre (bare for ca. 5-11 prosent av alle døve (Wie 2005)), derimot betegner førstespråk noe som for de fleste av oss er en selvfølgelighet; at man har et språk man behersker så utvunget og virtuost at 
man aldri trenger å være usikker på om man virkelig vil klare å si alt man ønsker med dette språket som verktøy.

Konsekvensene ved denne avdekkingen har vist seg vidtrekkende og bekrefter mange av de oppfatningene døve har artikulert om seg selv fra langt tilbake i tid og frem til i dag. Å være døv handler ikke nødvendigvis bare om ørets manglende funksjon, men også om tilhørighet i en språklig minoritet. Døve søker ikke sammen eller organiserer seg som gruppe bare for å fremme sine saker som funksjonshemmede. Døve søker fellesskap med hverandre slik det er naturlig å søke fellesskap med de som deler ens språk, og dermed kan også fellesskapet av døve beskrives som en kulturell minoritet: «Where people with disabilities cherish independence, culturally Deaf people cherish interdependence.» (Lane 1995: 180).

Selv om distinksjonen mellom døvhet og Døvhet altså ikke representerer mer enn en terminologisk differensiering som gjør at man kan skille mellom et fysisk hørselstap og det å være tegnspråklig, har deler av den bioetiske diskursen om d/Døvhet adoptert distinksjonen og transformert den til noe som ligner mer på en antinomi; gjensidig utelukkende tilnærminger til samme fenomen. De overnevnte bioetikerne insisterer på at fysisk døvhet må veie tyngst, og at døvhet er en funksjonshemming. De forutsetter da at det er mulig å teoretisk bestemme hva som er mest ontologisk signifikant, et naturgitt forhold eller det de ser som primært et sosialt fenomen. (Jeg har gjort mer detaljert rede for hvordan denne antinomien kunne genereres i Kermit 2007.) Når naturen gis prioritet, innebærer det en etablering av et bioetisk argument bygd på to premisser. Premiss én er biologisk-normativ: Døvhet (som fysisk tilstand) representerer noe mindre ønskelig for et menneske enn det å høre. Andre premiss er oppfatningen at Døve mennesker avviser denne biologisk-normative premissen. Candy McCulloughs og Sharon Duchesneaus handlinger tolkes som et uttrykk for at de to kvinnene anser sitt eget og sine barns fysiske hørselstap som et helt ubetydelig og underordnet forhold som minst av alt har noe med funksjonshemming å gjøre. Det bioetiske argumentet blir da at denne (påståtte) manglende anerkjennelsen av biologiens bestemmende rolle i forhold til hva som er en funksjonshemming, er irrasjonell og feilaktig.

For å lykkes med denne antinomiske tilnærmingen må man imidlertid ta utgangspunkt i bare de mest radikale utsagnene fra Døveaktivistisk hold (se f.eks. Lane 1993). Når det gjelder Candy McCullough og Sharon Duchesneau, er det lite i deres egne uttalelser som peker i retning av at de vil insistere på denne typen antinomi. De sier riktignok at de ikke ser på Døvhet som en funksjonshemming, men det de vektlegger, er at de ser sine livsprosjekter som tegnspråklige mennesker som like rike og meningsfulle som livsprosjektene til hørende mennesker (Mundy 2002). Det kan virke urimelig for et hørende menneske at kvinnene ikke ser det som funksjonshemmende at de ikke kan høre for eksempel lyder i naturen, egne barns gråt 
og latter, eller lyder som varsler fare eller musikk. Det er utvilsomt upraktisk å ikke høre i mange dagligdagse sammenhenger, men døve mennesker kan overvinne disse utfordringene enten ved å la andre sanser kompensere for fraværet av hørsel eller ved å innrette seg med teknologi som ikke krever lydoppfattelse. Når det gjelder estetiske lydbaserte opplevelser - for eksempel musikk og poesi - er det naturlig for et hørende menneske å tenke på fraværet av disse som et savn. For en som aldri har hatt disse opplevelsene, er det ikke like opplagt at for eksempel musikk bør savnes, og det gjelder kanskje for de fleste av oss at vi sjeldent knytter tapsfølelser til erfaringer som er helt utenfor vår rekkevidde. Tegnspråk har dessuten sin egen språklige visuelle estetikk, og Døve mennesker skaper poesi på sine språk akkurat som hørende gjør det på sine. Dermed er fravær av lydopplevelser i liten grad noe Døve mennesker opplever som funksjonshemmende, selv om fraværet opplagt innebærer at praktiske hinder må forseres i det daglige. Det som derimot oppleves som virkelig funksjonshemmende, er manglende anerkjennelse av at et liv med et tegnspråk er noe like autentisk som et liv med et talt språk:

[Sharon] grew up feeling that her [hearing] sister was normal and that she was flawed, a feeling, she says, exacerbated by her father, who pushed her to speak. She knows he meant well, and Sharon functioned so ably, it's easy to see why his expectations for her were high. But those standards filled her with a desire to meet them and a chronic sense of falling short. (Mundy 2002: W22)

Denne nyanseringen av hva som er utfordrende ved d/Døvhet, bør ikke oppfattes som en overfladisk dikotomi mellom en medisinsk modell av døvhet satt opp mot en sosial modell av Døvhet. Det er ikke motsetningene som er viktige, men heller det problematiske ved å essensialisere én forståelse og avvise en annen. Det trenger dermed på ingen måte å være uriktig at døvhet er en fysisk funksjonshemming, det uriktige består i å gjøre dette fokuset på det fysiske til det eneste som man vektlegger stilt overfor spørsmålet om seleksjon. Med en slik ensidig fokusering på det som er naturlig gitt, legger i tillegg Harris, Savulescu og Johnston seg svært nær den tidlige form for moderne normalitetsdiskurs som med en selvfølgelig moralsk autoritet anså det som ikke bare legitimt men også som etisk prisverdig å arbeide for å få bukt med alt man anså som sykelige avvik (Grue 2006).

\section{Andre premiss: om forskjellen på mindreverdig annenhet og likeverdig annerledeshet}

Historisk har de moderne normalitetsdiskursene om døvhet behandlet døve barn som mennesker med behov for å bli ført tilbake til en mer egent- 
lig tilstand. Disse diskursene har imidlertid ikke problematisert at det er en etisk omkostning forbundet med det å klassifisere noen som avvikere.

Allerede i løpet av andre halvdel av 1800-tallet ble (re)habilitering definert som den primære oppgaven til døveskolene. Selv om man ikke hadde teknologi eller metoder som kunne eliminere hørselsavvik, var målet likevel å få det døve barnet som i utgangspunktet var utenfor normen, til å nærme seg normen så mye som mulig. Som det antydes i sitatet ovenfor om Sharon Duchesneaus oppvekst var tilegnelsen av talespråk det altoverskyggende målet for opplæringen av døve barn. Tegnspråk har i denne sammenhengen blitt ansett som en mindreverdig kommunikasjonsform.

I Norge var det til langt ut på 1980-tallet en vanlig oppfatning at den viktigste oppgaven for døveskolene var å lære døve å tale og å prøve å oppfatte tale ved såkalt lyttetrening og terping på munnavlesning. Tegnspråkferdigheter ble ikke ansett som en nødvendig kvalifikasjon for å undervise på døveskolen, derimot utviklet spesialpedagogikken såkalte orale undervisningsmetoder og treningsopplegg. Mange døve har opplevd å streve mer med å forstå hva læreren sa, enn å forstå lærestoffet i seg selv. Taletreningen la i seg selv også beslag på så mye tid at mange etter endt skolegang ikke hadde rukket over vesentlige deler av det alminnelige grunnskolepensum. Et annet aspekt er at de som hadde hørselsrester og dermed bedre forutsetninger for å tale og høre, ble ansett som flinkere enn de som var helt døve. Anerkjennelse fra lærerne var med andre ord forbeholdt de som klarte å nærme seg normen, det å være hørende (Kermit 2006).

Det er historisk belegg (f.eks. Grønlie 2005; Kermit 2006; Kruth 1996) for å hevde at denne normalitetsdiskursen om døvhet både etablerte og fikk mange døve til å etablere seg som uautentiske andre. Jeg bruker her Simone de Beauvoirs begrep (1961). Det er en parallell mellom det hun så som kvinners manglende mulighet til autentisk identitetsdannelse og døve menneskers mulighet til selvrealisering. Beauvoir mener at kvinnen har vært henvist til å oppleve seg selv som uegentlig og annen i forhold til mannen, som på sin side har vært i en posisjon hvor han har kunnet oppfatte seg som egentlig og autentisk uten noen form for problematisering. Slik har også mange døve mennesker opplevd seg selv i forhold til hørende.

Igjen er det viktig å påpeke at dette ikke rokker ved at det er omkostninger ved det å ikke kunne høre, men de identitetsmessige omkostningene som omtales her, har ikke vært et direkte resultat av det fysiske hørselstapet, men et resultat av normalitetsdiskursens konstruksjon av døvhet som uønsket avvik og døveskolenes bestrebelser på å (re)habilitere døve barn. På tross av disse bestrebelsene overlevde tegnspråk som et språk som døve kun brukte seg imellom og overfor enkelte hørende (f.eks. sine egne barn). Det er i denne sammenhengen interessant at døveskolene (som så det som sin fremste oppgave å lære elevene å tale og å øve på taleoppfattelse) historisk har spilt rollen som det stedet hvor nye generasjoner døve barn tilegnet seg 
tegnspråk gjennom kontakt med eldre elever og voksne døve ansatte (som riktignok sjelden var lærere).

Det er på denne bakgrunnen vi må forstå betydningen av språkvitenskapenes avdekking av tegnspråk som naturlige språk. Avdekkelsen innebar en demaskering av et forhold som før hadde syntes naturlig betinget; at døve var mindreverdige i forhold til hørende fordi de ikke kunne høre. Isteden ble nå den manglende anerkjennelsen av tegnspråk den opplagte forklaringen på hvorfor mange døve for eksempel strevde med å fullføre sin grunnskoleutdanning. Samtidig var dette en bekreftelse av den identitetsmessige autentisiteten til alle de døve som hadde tegnspråk som sitt førstespråk: $\AA$ ha sin identitet knyttet til et tegnspråk er i teorien likestilt med en talespråklig artikulert identitet. I praksis innebærer tilhørighet til et tegnspråklig fellesskap ofte å tilhøre en språkminoritet, men det rokker i seg selv ikke ved språkets status som naturlig.

Å knytte begrepet om en autentisk identitet til språk på denne måten er det god støtte for i moderne filosofi: Charles Taylor (1992b) beskriver idealet om å danne en autentisk og unik identitet som et sentralt etisk aspekt ved moderne samfunn. Han poengterer flere steder $(1989 ; 1992 b)$ at denne moderne identitetsdannelse er blitt et sårbart prosjekt. Mens identitet tidligere var noe man i høy grad ble tildelt ut fra sin plass i fellesskapet, kjennetegnes det moderne ved begrepet om enkeltmenneskets verdighet. Idealet om en autentisk, individualisert identitet henger nøye sammen med verdighetsbegrepet, for tanken om verdighet er historisk forbundet med tanken om at hver enkelt av oss har sin unike måte å være i verden på. Det moderne kjennetegnes dermed også ved et originalitetsprinsipp. Enhver definerer seg selv gjennom å artikulere sin originalitet, og siden enhver har sin egen målestokk får autentisitetsidealet også en etisk betydning. Fordi selvartikuleringen har en dialogisk karakter, er det viktig å bli anerkjent for den man er. Individet må ha både et fullt naturlig språk og andre å henvende seg til både for å gi og for å motta anerkjennelse. Her viser Taylor (1992b) til George Herbert Meads begrep om signifikante andre som nøkkelpersoner i den dialogiske prosessen. Hvorfor dette er et sårbart prosjekt, blir her tydelig: Den som ikke mottar anerkjennelse, kan mislykkes i å utvikle en autentisk selvrelasjon. Axel Honneth går lenger enn Taylor og beskriver det å holde tilbake anerkjennelse overfor et medmenneske som en potensiell etisk krenkelse (Honneth 2003). Det innbærer vel og merke ikke at vi ukritisk skal gi vår tilslutning til enhver fordring om anerkjennelse.

Når døve definerer seg som en språklig minoritet, innebærer det også et element av opplevd krenkelse gjennom å bli behandlet som uegentlige hørende, noe som utvilsomt er noe av bakgrunnen for at det fra Døveaktivistisk hold ofte har vært fremholdt at Døve ikke er funksjonshemmede. Som jeg har vært inne på ovenfor, er det likevel for enkelt å akseptere en dikotom motsetning mellom to modeller for $\mathrm{d} / \mathrm{Døvhet}$, der den siste er et 
slags sosialt konstruert opprør mot medisinen eller naturen. Det er vesentlig å skille mellom en identitetskonstruksjon som undertrykt språklig minoritet, som mange Døve har gjort, og det perspektivet som tilsier at identitetsdannelse blott og bart, og ikke som en bestemt type identitet, er like mulig og tenkelig med et tegnspråk som førstespråk som med et talt språk som førstespråk. Det er det siste perspektivet som er konstituerende for premissen som tilsier at Døves livsprosjekter har samme potensial for autentisitet som hørende menneskers livsprosjekter. Hvis Døve barn ikke hadde annen mulighet enn å anta en identitet som aktivister i opprør mot hørende, ville dette kanskje i seg selv være et argument mot seleksjon for døvhet, noe Kyle W. Anstey (2002) har argumentert for.

Å være d/Døv er forbundet med omkostninger eller prøvelser. Det er upraktisk å ikke høre i en verden der mye er basert på lyd. Likevel, denne ulempen truer ikke et døvt barns potensial for autentisk identitetsdannelse, dersom barnets omgivelser anerkjenner at barnet kan tilegne seg et tegnspråk. Nøkkelen til overvinnelse av hørselsbarrieren som en kommunikasjonsbarriere er opparbeidelsen av en god tospråklig kompetanse. Da vil barnet få adgang ikke bare til et tegnspråkfellesskap, men til hele samfunnet. Tilegnelse av et talt språk er ikke irrelevant, men slik tilegnelse vil sannsynligvis bli lettere for døve barn dersom de kan lære talespråk ved kontrastiv språkinnlæring på basis av et tegnspråk som de opplever som anerkjent og likestilt med talespråk. Denne tilnærmingen som anerkjenner viktigheten ikke bare av ett, men av to språk - og som Norges Døveforbund går inn for - er en overskridelse av den konstruerte dikotomien mellom døvhet og Døvhet. Det er vanskelig å se for seg, både teoretisk og praktisk, at Døve som språkminoritet skal kunne tilby sine medlemmer en fullstendig livsverden innenfor et eget tenkt «språkreservat». Derimot antyder Taylors betraktninger om språkminoriteters behov for anerkjennelse et begrep om likeverdig annerledeshet som tilsier at samfunnet må legge til rette både for at minoriteten skal kunne bestå i kraft av sin egenart $o g$ for at minoritetens medlemmer skal være sikret tilgang til de samme tilbud og muligheter for livsutfoldelse som alle andre (Taylor 1992b). En god tospråklig utdanning av døve barn er viktig i denne sammenhengen.

\section{Tredje premiss: forholdet mellom tilvalg og fravalg}

Premiss én og to impliserer at dersom man forsvarer seleksjon av et hørende barn, kan man ikke konsistent kritisere det motsatte; seleksjon av et døvt barn. Det er begrunnet med at et liv som tegnspråklig Døv har samme potensial for autentisk livsutfoldelse som et liv som hørende. Dette er imidlertid et helt teoretisk standpunkt som overhodet ikke tar inn over seg hva seleksjon i seg selv innebærer. 
«Medisinsk reproduktiv teknologi» er ikke en spesielt presis term. Det er derfor nødvendig å gjøre noen avgrensninger. Når det gjelder teknologi som tillater vordende foreldre med en genetisk disposisjon for arvelig døvhet å foreta til- eller fravalg av hørsel hos fremtidige barn, er det i dag to metoder som gir høy grad av sikkerhet for valget som er gjort: prenatal genetisk testing av foster med eventuell påfølgende selektiv abort, og in vitro fertilisering med forutgående genetisk testing av det befruktede egget som implanteres (den siste metoden omtales vanligvis som preimplantasjonsdiagnostikk, PGD (Dennis 2004)).

Disse teknikkene gir kun viten om hvorvidt et foster eller et befruktet egg har genetisk disposisjon som med stor sikkerhet medfører døvhet eller ikke. Man er ennå langt fra å kunne gi behandling (genterapi) til et foster eller et befruktet egg som endrer genetiske disposisjoner (Vehmas 2002), så hvis man finner at et foster som testes ikke har den foretrukne hørselsstatus, må foreldrene ta valget om å abortere det aktuelle fosteret og satse på å unnfange et nytt (Shakespeare 1999).

Med PGD har man muligheten til å sikre seg at det befruktede egget som settes inn i morens livmor, har den genetiske disposisjonen som er foretrukket i forhold til hørsel. Metoden fordrer imidlertid at flere egg høstes, blir befruktet utenfor livmoren og testes. Det er bare det befruktede egget som blir brukt, som har mulighet til å utvikle seg til et barn. De befruktede eggene som ikke har den foretrukne genetiske disposisjon for hørsel, destrueres.

Slik jeg formulerer meg her, relativeres skillet mellom fravalg og tilvalg på to måter: For det første legger jeg her til grunn at uansett om det man gjør karakteriseres som fravalg eller tilvalg når man involverer én av de to metodene beskrevet ovenfor, involverer bruken av metodene muligheten for at noe - et foster eller ett eller flere befruktede egg - velges bort.

For det andre utfordrer dette de deler av den bioetiske debatten som først og fremst har vært opptatt av å diskutere den etiske forsvarligheten ved fravalg av sykdom eller skade, og som i mange sammenhenger legger opp til at fravalg er mindre problematisk enn tilvalg (se f.eks. Shakespeare 2006). Med det fokus på autentisitetsargumentet som jeg legger til grunn i denne artikkelen, reises i en viss forstand spørsmålet om ikke fravalg av døvhet som vanligvis oppfattes som skade - samtidig må oppfattes som en mer aktiv form for tilvalg av hørsel. Med fokus på autentisitetsspørsmålet blir det utilfredsstillende å hevde at det bare er tilvalg av døvhet som representerer et aktivt tilvalg, mens det motsatte er et mindre problematisk fravalg. 


\section{Fjerde premiss: forholdet mellom seleksjonens etiske omkostning og hva det selekteres for}

Den etiske vurderingen av de to ovenfornevnte metodene er sentral i flere pågående bioetiske diskurser som spenner fra funksjonshemmedeforskning til teknologivurdering. Diskursene involverer mange komplekse problemstillinger, blant annet knyttet til spørsmålet om abort eller spørsmål som når i utviklingsprosessen fra befruktet egg til nyfødt barn man kan tilskrives menneskeverd eller har krav på en eller annen form for beskyttelse. Slik jeg utformer argumentasjonen her, er det imidlertid ikke nødvendig å ta kategorisk stilling til slike spørsmål så lenge man aksepterer grunnpremissen; at bruk av disse to nevnte metodene - som gir høy grad av mulighet for resultatprediksjon - innebærer at noe som potensielt kunne blitt et menneske, kan komme til å bli valgt bort.

Jeg legger ikke til grunn at dette er etisk uforsvarlig i enhver situasjon, men med den spesifikke diskusjonen om døvhet som bakteppe vil jeg foreslå som en moderat tilnærming at i spørsmål om til-/fravalg, bør man se at de nevnte metodenes generelle etiske kostnad - at noe velges bort - er av en såpass alvorlig karakter at metodene ikke bør brukes når forskjellene på det man velger til eller fra, er små.

Med denne tilnærmingen foreslår jeg en mye svakere verdipremiss enn for eksempel den norske bioteknologiloven. For det første gjenspeiler lovverket at man erkjenner at det er en etisk omkostning forbundet med bruken av teknologien, og derfor skal man i dag ha tungtveiende grunner hvis man skal få bruke PGD. Det eneste man hittil har gitt åpning for, er bruk av denne teknologien som et middel til fravalg av «[...] alvorlig monogen eller kromosomal arvelig sykdom [der] det er stor fare for at sykdommen kan overføres til et kommende barn» (lov om humanmedisinsk bruk av bioteknologi m.m. \$2A-1). For det andre uttrykker loven klart at man ikke godtar seleksjon av egenskaper som er uvesentlige for andre faktorer enn sterkt forringet livskvalitet på grunn av sykdom. Tydeligst i forhold til dette er forbudet mot kjønnsseleksjon. Seleksjonens premiss er at den ikke bare kan representere en smaksdom, men at det er uomtvistelig at det man velger bort, representerer noe mye mindre ønskelig enn det man velger.

\section{Konklusjon med implikasjoner og en desisjonistisk restproblematikk}

De fire ovenstående premissene indikerer konklusjonen at både seleksjon av et døvt eller et hørende barn er like etisk problematisk fordi valgene dette impliserer, er valg mellom livsprosjekter som potensielt er like autentiske. Det kan ikke benektes at det kan innebære prøvelser å ikke høre, men når 
man tar i betraktning den generelle etiske omkostningen ved seleksjon - at noe som har potensial til å bli ett eller flere individ, velges vekk - peker dette likevel i retning av denne negative konklusjonen: Fordi vi ikke kan godta at det er vesentlig bedre å høre enn å være døv, kan vi heller ikke godta seleksjon av noen av delene, all den tid seleksjon generelt innebærer en etisk kostnad. Konklusjonen baseres på at man istedenfor å la fysiske avvikstilstander gjelde som enkeltstående kriterium for seleksjon, legger autentisitetsbetraktninger til grunn.

Denne argumentasjonsmåten representerer i og for seg ikke noe nytt. Flere andre deltakere i bioetiske diskurser om fravalg av funksjonshemming har stilt seg kritisk til å selektere på basis av bare fysiologiske egenskaper (se f.eks. Reindal 2000). Mange av disse bidragsyterne har basert sin kritikk på argumenter om menneskeverd, livskvalitet og hva som er et leveverdig liv (Shakespeare 2006; Solberg 2003). Uten å gå inn i en uttømmende drøfting vil jeg påpeke at autentisitetsargumentet på den ene siden kan plasseres tett opp til disse andre argumentene: Taylor knytter som sagt begrepet om en autentisk identitet tett sammen med det moderne menneskeverdbegrepet. I og med at det er ens unike potensial som skal realiseres, ligger det også i sakens natur at det er problematisk å stille opp objektive kriterier for hva som skal telle som «tilstrekkelig» potensial for autentisk identitetsdannelse.

På den andre siden kan det være vesentlige ulikheter som tilsier at argumentene adresserer ulike aspekter i de respektive diskusjonene: Selv om autentisitet knyttes til et unikt livsprosjekt er Taylors begrep om autentisitet også sterkt knyttet til det å virkeliggjøre seg som et språklig, rasjonelt, sosialt og moralsk kompetent individ. Likeverdighetsbegrepet som legges til grunn, er altså knyttet til rasjonalitet, språk og kognisjon. Dermed er det ikke uten videre opplagt at autentisitetsbetraktninger slik de er utformet her kan gjelde for eksempel der et menneske har betydelige kognitive utfordringer knyttet til språktilegnelse og læring. I et slikt tilfelle kan argumenter om menneskeverd, livskvalitet og hva som er et leveverdig liv ha større argumentativ relevans.

Det er videre to implikasjoner som følger av konklusjonen: Den første angår spørsmålet om etisk forsvarlighet ved å unnfange et barn når man vet at det er en mulighet for at barnet kan være døvt. Den andre angår legitimiteten ved det å ønske seg et barn i sitt bilde. Endelig er det en desisjonistisk restproblematikk knyttet til det lesbiske paret som er nevnt innledningsvis og som er brukt som eksempel i første og andre premiss ovenfor. Denne restproblematikken kan ikke løses innen rammene av argumentasjonen som brukes her.

At det ikke lar seg gjøre å uttømme alle identifiserte etiske aspekter ved hjelp av autentisitetsbetraktninger, er ikke i seg selv problematisk. Taylor er kritisk til det han ser som nåtidige forsøk på å utarbeide et snevert begrep om det moralske, hvor etiske vurderinger skal kunne føres tilbake på ett 
enkelt kriterium (Taylor 1989). Han gir historiske eksempler på at gale konklusjoner av og til kan ha vært støttet av riktige premisser og omvendt. Derfor er det i Taylors ånd å anse som en fordel når et etisk problem kan belyses gjennom ulike tilnærminger. Når det gjelder spørsmålene for eller mot seleksjon av $\mathrm{d} /$ Døvhet har autentisitetsbetraktningene relevans særlig fordi de tar opp i seg døve menneskers egen artikulering av hva d/Døvhet innebærer. Å hevde at denne tilnærmingen er den eneste riktige, vil imidlertid slå beina under hele denne fremstillingen.

Argumentasjonen i premissene 1-4 ovenfor retter seg mot de spesielle tilfellene hvor det selekteres for eller mot døvhet ved hjelp av enten fosterdiagnostikk med mulighet for selektiv abort, eller PGD. Når det gjelder tilvalg av døvhet ved hjelp av PGD, vil dette vanskelig la seg gjøre i land med streng offentlig regulering av bioteknologifeltet. At PGD er blitt brukt med motsatt fortegn - for å sikre et hørende barn - kjenner man i alle fall ett dokumentert tilfelle av i Australia (Dennis 2004; Johnston 2005). Man vet lite om omfanget av fosterdiagnostikk i relasjon til døvhet. Et døvt par som venter barn, kan enkelt oppnå slik testing hvis de sier de er bekymret, og kan deretter abortere fosteret innen den legitime grensen for selvbestemt abort dersom de ikke ønsker et hørende barn. Undersøkelser indikerer imidlertid at dette må være svært sjelden (Dennis 2004). Det som derimot er vanlig, er at døve menn og kvinner inngår samboer- eller ekteskap - dette gjelder for ca. 90 prosent av alle døve i Norden (Grønlie 2005) - og får barn uten noen form for assistanse. Tallene spriker, men man antar at mellom $5 \mathrm{og} 10$ prosent av disse barna blir døve av arvelige årsaker. Ona Bø Wie fant i sin studie av de 100 første cochleaimplanterte barna i Norge at drøyt 11 prosent var døve på grunn av arv (Wie 2005). Det er altså en helt relevant problemstilling dersom man spør om den etiske siden ved å forplante seg når man vet om denne typen mulighet for døvhet.

Konklusjonen ovenfor legger til grunn at det å være døv eller hørende ikke er en vesentlig forskjell når det gjelder potensial for autentisk identitetsdannelse, og at omkostningen ved å ville selektere er for høy i forhold til forskjellen på det man selekterer mellom. Overført til spørsmålet om naturlig forplantning med kunnskap om genetisk disposisjon for døvhet kan den samme betraktningen gjøres gjeldende: Den etiske omkostningen det er for et par å unngå et døvt barn, er vesentlig høyere enn det er å ta ansvar for å sette et mulig døvt barn til verden, ikke minst dersom foreldrene i utgangspunktet har den holdningen at barnets livsprosjekt vil ha lik mulighet for autentisitet uavhengig av hørselsstatus. Å la seg teste for å bestemme graden av risiko for døvhet man utsetter sine fremtidige barn for, eller å teste et allerede unnfanget foster, leder i seg selv til de omtalte etiske problemstillingene som PGD og selektiv abort involverer. Ved dette punktet kan frivillig barnløshet anføres som siste mulighet (se f.eks. Rosamond 1998). Dette er etisk sett vanskelig å klandre, men akkurat i tilfellet med døvhet er det 
såpass ekstremt at det gir grunn til å reflektere over rekkevidden av betraktningene om autentisitet igjen.

Et aspekt som berøres i disse diskusjonene er spørsmålet om det legitime ved å ønske seg barn «i sitt eget bilde» (Anstey 2002). Det kan det være nærliggende å mene at autentisitetsbetraktningene som her legges til grunn, kunne forsterke oppfatningen at foreldre må kunne få barn som er mest mulig som dem selv, og som ikke må forventes å bli fremmede for sitt opphav på et fremtidig tidspunkt. Et slikt synspunkt er imidlertid bare mulig for den som synes at det er et stort kulturelt gap mellom det å være Døv eller hørende. Jeg har her argumentert mot forsøkene på å lage dikotome motsetninger, og insisterer tvert imot på at det å være Døv ikke må forstås som å være atskilt fra det hørende samfunn. Dette argumentet virker også motsatt; hørende barn av døve har alle forutsetninger for å tilegne seg god tospråklig kompetanse (noe det også er godt forskningsmessig belegg for, se f.eks. Grønlie 2005). Denne typen argumenter baserer seg dermed på sviktende forutsetninger dersom man ønsker å bruke dem for å legitimere seleksjon. En annen sak er at autentisitetsbetraktningene i høy grad støtter det legitime ved å ønske seg barn i sitt bilde. At slike ønsker finnes, er det forskningsmessig belegg for: Man har dokumentert hvordan døve mødre som får et hørende barn etter å ha fătt ett eller flere døve, beskriver sine reaksjoner svært analogt med hørende mødre som får et døvt barn (Grønlie 2005).

I saken som involverer det lesbiske paret Candy McCullough og Sharon Duchesneau, gjenstår det imidlertid en restproblematikk, selv om man skulle akseptere samtlige slutninger ovenfor. Som nevnt hadde paret brukt kunstig inseminasjon med hjelp fra en døv sæddonor som hadde en kjent disposisjon for arvelig døvhet. Det man først kan merke seg, er at ingen potensielle livsprosjekter ble fravalgt ved denne lavteknologiske metoden. Dette blir gjerne oversett. I Norge ble saken trukket frem som et eksempel på uønsket bruk av PGD i sosialkomiteens innstilling til evaluering av bioteknologiloven (Solberg 2003). Paret faller ikke inn under det som er hovedtematikken her; nemlig til- eller fravalg ved hjelp av teknologi som gir høy prediktiv sikkerhet. Samtidig er det heller ikke opplagt at paret helt uten videre kan sammenlignes med heterofile døve som finner en døv partner og får barn med eller uten viten om mulighet for arvelig videreført døvhet. Ifølge McCulloughs og Sharon Duchesneaus egne uttalelser var deres valg av donor et bevisst strategisk trekk for å øke sjansen for å få et døvt barn. Som nevnt ovenfor argumenterer jeg her for legitimiteten ved å ha et ønske om et barn «i sitt bilde» og hvis dette hadde vært et spørsmål om etnisitet, ville de færreste ha stilt spørsmålstegn ved et par som ønsket en donor med lignende hud- og hårfarge som dem selv. Jeg har imidlertid argumentert mot at døvhet kan sees kun som et kulturelt og språklig fenomen uten samtidig å ta med i betraktningen det fysiske hørselstapet (selv om jeg har argu- 
mentert for at det i mange sammenhenger er helt underordnet). Selv om man kan anføre flere rimelighetsbetraktninger når det gjelder parets valg av donor, kan jeg ikke se at man kan redusere helt et element av intendert seleksjon i dette tilfellet. Denne typen intensjonalitet bekymrer Jürgen Habermas, som mener at seleksjonen i seg selv kan begrense det selekterte individets autonomi (Habermas 2003). Jeg har her begrenset meg til å argumentere mot én bestemt form for seleksjon - for eller mot døvhet - ved å vise til dens omkostninger i form av fravalg sett i forhold til autentisitetsbetraktninger, og har slik sett ikke tatt stilling til tenkte eller reelle tilfeller hvor seleksjonen ikke har slik omkostning. Hvordan saken stiller seg dersom omkostningene ved en seleksjon kan sies å være etisk insignifikante, blir dermed tema for en annen diskusjon.

\section{Litteratur}

Anstey, K. W. (2002) Are attempts to have impaired children justifiable? Journal of Medical Ethics, 28 (5), s. 286-288.

Armstrong, D. F., Karchmer, M. A. \& Van Cleve, J. V. (2002) The study of signed languages: Essays in honor of William C. Stokoe. Washington DC: Gallaudet University Press.

Beauvoir, S. D. (1961) The second sex. New York: Bantam Books, Inc.

Dennis, C. (2004) Deaf by design. Nature, 431 (7011), s. 894-896.

Endresen, R. T., Simonsen, H. G. \& Sveen, A. (red.) (1996) Innføring i lingvistikk. Oslo: Universitetsforlaget.

Grønlie, S. M. (2005) Uten hørsel? En bok om hørselshemming. Bergen: Fagbokforlaget.

Grue, L. (2006) Normalitetens oppfinnelse. I Normalitet, red. T. H. Eriksen \& J.-K. Breivik, s. s. 25-48. Oslo: Universitetsforlaget.

Habermas, J. (2003) Den menneskelige naturs fremtid. Oslo: N.W. Damm \& søn.

Harris, J. (2000) Is there a coherent social conception of disability? Journal of Medical Ethics, 26, s. 95-100.

Harris, J. (2002) One principle and a fourth fallacy of disability studies. Journal of Medical Ethics, 28 (3), s. 204.

Hayry, M. (2004) There is a difference between selecting a deaf embryo and deafening a hearing child. Journal of Medical Ethics, 30 (5), s. 510-512.

Helse- og omsorgsdepartementet (2003) Lov om humanmedisinsk bruk av bioteknologi m.m. (bioteknologiloven). Oslo: Helse- og omsorgsdepartementet.

Honneth, A. (2003) Mellan Aristoteles och Kant. I Erkännande. Praktisk-filosofiska studier, red. A. Honneth, s. 87-110. Göteborg: Daidalos.

Johnston, T. (2005) In one's own image: Ethics and the reproduction of deafness. Journal of Deaf Studies and Deaf Education, 10 (4), s. 426-441.

Kermit, P. (2006) Tegnspråk og anerkjennelsen av døve som en språklig minoritet. I Tegn som språk: En antologi om tegnspråk, red. S. R. Jørgensen \& R. L. Anjum, s. 47-59. Oslo: Gyldendal Akademisk. 
Kermit, P. (2007) Bioethical discourses on deafness: Critical remarks and suggestions for a new approach. I Constructing educational discourses on deafness, vol. 17, red. M. Hyde \& G. Høie, s. 40-57. Oslo: Skådalen ressurssenter.

Kruth, L. (1996) En tyst värld - full av liv. Örebro: SIH Läromedel.

Lane, H. (1993) Cochlear implants: Their cultural and historical meaning. I Deaf history unveiled: Interpretations from the new scholarship, red. J. V. Van Cleve, s. 272-291. Washington DC: Gallaudet University Press.

Lane, H. (1995) Constructions of deafness. Disability, Handicap \& Society, 10 (2), s. 171-189.

Markowicz, H. \& Woodward, J. (1978) Language and maintenance of ethnic boundaries in deaf community. Communication and Cognition, 11 (1), s. 29-38.

Meland, A. (2002) Er døv fordi foreldrene vil det. Dagbladet, 9. april 2002. Lastet ned fra http://www.dagbladet.no/dinside/2002/04/09/323 694.html

Mills, M. (2002) I'm happy my child is deaf. The Guardian, 9. april 2002, s. 8.

Mundy, L. (2002) A world of their own. The Washington Post, 31. mars 2002, s. W22.

Reindal, S. M. (2000) Disability, gene therapy and eugenics - a challenge to John Harris. Journal of Medical Ethics, 26 (2), s. 89-94.

Rosamond, R. (1998) Genetic links, family ties, and social bonds: Rights and responsibilities in the face of genetic knowledge. The Journal of Medicine and Philosophy, 23 (1), s. 10-30.

Savulescu, J. (2002) Deaf lesbians, «designer disability,» and the future of medicine. BMJ, 325 (7367), s. 771-773.

Shakespeare, T. (1999) "Losing the plot»? Medical and activist discourses of contemporary genetics and disability. Sociology of Health and Illness, 21 (5), s. 669-688.

Shakespeare, T. (2006) Disability rights and wrongs. London: Routledge.

Solberg, B. (2003) Sortering av liv? Etiske hensyn ved å lage barn med og uten genetisk risikoinformasjon. Dr.art.-avhandling. Trondheim: Filosofisk institutt, Det historisk-filosofiske fakultet, NTNU.

Stokoe, W. C. Jr. (2005) Sign language structure: An outline of the visual communication systems of the American deaf. The Journal of Deaf Studies and Deaf Education, 10 (1), s. 3-37.

Taylor, C. (1989) Sources of the self. The making of the modern identity. Cambrigde, Massachusetts: Harvard University Press.

Taylor, C. (1992a) The ethics of authenticity. Cambrigde, Massachusetts \& London, England: Harvard University Press.

Taylor, C. (1992b) The politics of recognition. I Multiculturalism and the politics of recognition, red. A. Gutman, s. 25-73. Princeton: Princeton University Press.

Vehmas, S. (2002) Is it wrong to deliberately conceive or give birth to a child with mental retardation. Journal of Medicine and Philosophy, 27 (1), s. 47-63.

Wie, O. B. (2005) Kan døve bli hørende? En kartlegging av de hundre første barna med cochleaimplantat i Norge. Oslo: Unipub Forlag. 